\title{
DIET OF THE MOHAVE GROUND SQUIRREL (XEROSPERMOPHILUS MOHAVENSIS) IN RELATION TO SEASON AND RAINFALL
}

\author{
Barbara M. Leitner ${ }^{1}$ and Philip Leitner ${ }^{2}$
}

\begin{abstract}
The Mohave ground squirrel (Xerospermophilus mohavensis) is endemic to the western Mojave Desert of California. It is listed as threatened under the California Endangered Species Act, yet there is little published information on its habitat requirements. We studied the diet of Mohave ground squirrels at 4 sites in desert scrub habitat in Inyo County, California, primarily by microhistological analysis of 754 samples of fecal pellets collected from live-trapped animals. Over all sites and seasons, shrub foliage was the largest component of the diet (39.8\% relative density) and mainly derived from several taxa of Chenopodiaceae: winterfat (Krascheninnikovia lanata), spiny hopsage (Grayia spinosa), and saltbushes (Atriplex spp.). Forb leaves were next in importance (34.1\% relative density), especially from Fabaceae (Astragalus and Lupinus), Polemoniaceae (Gilia and Linanthus), and Asteraceae. Flowers, pollen, and seeds were also major components ( $20.3 \%$ relative density). Leaves composed nearly all of the diet in spring, whereas pollen, flowers, and seeds made up about a third of the diet in summer. Following dry winters when annual forbs were limited, Mohave ground squirrels depended primarily on foliage from perennial shrubs and forbs. Following wet winters when spring annuals were abundant and most plant species flowered and set seed prolifically, squirrels consumed a high proportion of leaves plus flowers, pollen, and seeds of annual forbs. Mohave ground squirrels reproduced only after winter rainfall $>80 \mathrm{~mm}$ that resulted in a standing crop of herbaceous annuals $\geq 100 \mathrm{~kg} \cdot \mathrm{ha}^{-1}$. Mohave ground squirrels consumed very little of the nonnative annual plant biomass present on our study sites (Erodium, Salsola, Bromus, and Schismus contributed $<3 \%$ overall to the diet). Conservation implications include the following: (1) priority should be given to protecting habitats supporting preferred perennial forage plants, including winterfat and spiny hopsage; (2) habitats with an understory dominated by native annual forbs have higher value than those dominated by nonnative plants, especially annual grasses; and (3) if climate change results in lower and less regular winter precipitation, suitable habitat for Mohave ground squirrels may be reduced and fragmented in the drier portions of the geographic range.
\end{abstract}

Resumen.—La ardilla de Mojave (Xerospermophilus mohavensis) es endémica de la región occidental del desierto de Mojave, situado en California. Esta especie se encuentra en la lista de la Ley de California de las Especies como en peligro de extinción, sin embargo, existe poca información publicada acerca de sus requerimientos de hábitat. Estudiamos la dieta de las ardillas de Mojave en cuatro sitios de matorral desértico en el condado de Inyo, California, principalmente mediante el análisis microhistológico de 754 muestras fecales colectadas de animales vivos capturados en trampas. En todos los sitios y estaciones, el follaje arbustivo fue el componente más importante de la dieta de las ardillas, con una densidad relativa de $39.8 \%$, derivado principalmente de varios taxa de Chenopodiaceae: Krascheninnikovia lanata, Grayia spinosa y Atriplex spp. Las hojas de hierbas siguieron en importancia con una densidad relativa de 34.1\%, especialmente de Fabaceae (Astragalus y Lupinus), Polemoniaceae (Gilia y Linanthus) y Asteraceae. Las flores, el polen y las semillas fueron también componentes importantes, formando parte del $20.3 \%$ de la densidad relativa. Casi toda la dieta en primavera fue de hojas, mientras que el polen, las flores y las semillas constituían casi un tercio de la dieta en verano. Después de los inviernos secos, cuando las hierbas anuales eran limitadas, las ardillas de Mojave dependieron principalmente de follaje de arbustos y de hierbas perennes; después de los inviernos húmedos, cuando las plantas anuales de primavera eran abundantes y la mayoría de las especies de plantas florecieron y sembraron semillas prolíficamente, las ardillas consumieron una alta proporción de hojas, además de flores, polen y semillas de hierbas anuales. Las ardillas de Mojave se reprodujeron sólo después de lluvias invernales $>80 \mathrm{~mm}$ que resultaron en un cosecha en pie de hierbas anuales $\geq 100 \mathrm{~kg} \cdot \mathrm{ha}^{-1}$. Las ardillas de Mojave se alimentaron muy poco de plantas anuales no nativas que se encontraban en nuestros sitios de estudio (Erodium, Salsola, Bromus y Schismus contribuyeron con menos de 3\% de la dieta total). Las implicaciones de conservación incluyen: (1) la prioridad debe ser la protección de los hábitats que tienen plantas perennes, incluyendo a K. lanata y G. spinosa; (2) los hábitats con un sotobosque dominado por hierbas anuales nativas tienen un valor más alto que los dominados por plantas no nativas, especialmente las hierbas anuales; y (3) si el cambio climático resulta en una menor y más irregular precipitación invernal, el hábitat adecuado podría reducirse y fragmentarse en las partes más secas de su rango geográfico.

The Mohave ground squirrel (Xerospermophilus mohavensis [formerly Spermophilus mohavensis; Helgen et al. 2009]) is found only in desert scrub habitats in the western Mojave Desert of California (Best 1995). It is listed as threatened under the California Endangered

\footnotetext{
12 Parkway Court, Orinda, CA 94563.

${ }^{2}$ Corresponding author. Biology Department, St. Mary’s College of California, Moraga, CA 94575. E-mail: pleitner@stmarys-ca.edu
} 
Species Act due to its limited and patchy distribution, relatively low abundance, and habitat loss from human land uses (Gustafson 1993). Mohave ground squirrels are active aboveground from February through July (Bartholomew and Hudson 1960). When conditions allow during this period, adults reproduce and then accumulate fat reserves in preparation for prolonged dormancy, approximately doubling in body mass from 70-80 $\mathrm{g}$ to $\geq 165$ g (Best 1995). Mohave ground squirrels accomplish these physiological feats in an arid environment with highly variable annual precipitation. Effective conservation of the species requires an understanding of its habitat requirements and dietary patterns.

There are few published accounts of Mohave ground squirrel diet and feeding behavior. Recht (1977) observed 8 radio-collared individuals feeding on 11 plant taxa. Zembal and Gall (1980) reported incidental observations of Mohave ground squirrels feeding on the fruit and seeds of Joshua trees (Yucca brevifolia). No dietary data have been published based on the analysis of stomach contents or fecal material.

This study was carried out as part of a long-term ecological investigation of Mohave ground squirrel demography, movements, and habitat use (Leitner and Leitner 1998). The objective of this element of the study was to determine whether food requirements could help to characterize the essential habitat of this cryptic species, thus facilitating its conservation and management. The need for an understanding of habitat requirements is especially acute because the species occupies a region that is a high priority for renewable energy development.

\section{Methods}

\section{Study Area}

The study area was situated in and near the Coso Range, about $20 \mathrm{~km}$ east of the Sierra Nevada in the northwestern Mojave Desert, Inyo County, California $\left(36^{\circ} 04^{\prime} \mathrm{N}, 117^{\circ} 48^{\prime} \mathrm{W}\right)$. We established four 25-ha sites that ranged in elevation from $1000 \mathrm{~m}$ to $1500 \mathrm{~m}$ and were located on fine- to coarse-textured alluvial soils derived from igneous parent material. During the 9-year study from 1988 to 1996, annual precipitation averaged $140 \mathrm{~mm}$ at the Haiwee Power Plant, about $15 \mathrm{~km}$ to the northwest. Winter rainfall predominated, with
$82 \%$ of mean annual precipitation $(115 \mathrm{~mm})$ received between 1 October and 31 March. Winter precipitation differed drastically between years, ranging from $14 \mathrm{~mm}$ (1989/1990) to $234 \mathrm{~mm}(1992 / 1993)$.

All 4 sites supported chenopod scrub represented by several vegetation alliances as defined in Sawyer et al. (2009). Site 1, located in Rose Valley just west of the Coso Range at $1015 \mathrm{~m}$ elevation, supported Atriplex polycarpa (allscale) and Atriplex confertifolia (shadscale) alliances. Both shrub cover (9\%) and species richness were low, although annual herbaceous production was high. Joshua trees (Yucca brevifolia) were not present on the site and were rare nearby. Site 2 , in the Coso Basin at $1085 \mathrm{~m}$ elevation, supported primarily Atriplex confertifolia and Ephedra nevadensis (Nevada jointfir) alliances. This site was dominated by low-stature shrubs including rayless goldenhead (Acamptopappus sphaerocephalus), Nevada jointfir, shadscale, cheesebush (Ambrosia [= Hymenoclea] salsola), and winterfat (Krascheninnikovia lanata). A few Joshua trees (Yucca brevifolia) were adjacent to site 2 . Shrub cover $(27 \%)$ and species richness were high and annual herbaceous production low. Joshua trees were not present on the site and were rare nearby. Site 3, situated in a small valley in the Coso Range at $1470 \mathrm{~m}$ elevation, supported Atriplex confertifolia, Atriplex canescens (fourwing saltbush), and Grayia spinosa (spiny hopsage) alliances. This site was codominated by spiny hopsage, shadscale, fourwing saltbush, and Cooper's boxthorn (Lycium cooperi). Joshua trees were present over much of site 3 , with an average density of 17 per hectare. Shrub cover (16\%) and species richness were high, and annual herbaceous production was also high. Site 4, located in a valley at $1500 \mathrm{~m}$ elevation in the Coso Range, supported Grayia spinosa and Ephedra nevadensis alliances. Shrub cover $(20 \%)$ and species richness were similar to site 3, but annual herbaceous production was generally lower. Joshua trees were present at an average density of 15 per hectare.

\section{Sample Collection and Analysis}

We collected fecal samples from animals captured during regular trapping sessions. Each site was $500 \times 500 \mathrm{~m}$ and contained an array of 441 traps spaced $25 \mathrm{~m}$ apart in a $21 \times$ 21 configuration (Leitner and Leitner 1998). 
Pymatuning $(10 \times 11 \times 39 \mathrm{~cm})$ and Sherman $(8 \times 9 \times 23 \mathrm{~cm})$ live traps were used. Trapping was carried out in spring (early March to mid-April) in 1990 and 1992-1996, and in early summer (late May to mid-June) during all 9 years. When an animal was captured, we collected fecal pellets according to instructions from the Composition Analysis Laboratory at Fort Collins, Colorado (T. Foppe, personal communication, 1988). Three individual pellets were shaken from the trap, placed in a labeled paper envelope, and allowed to air-dry, which occurred quickly in this arid environment. We then emptied the trap of all remaining fecal material. As many individuals as possible were represented in the samples analyzed, but when few Mohave ground squirrels were captured, we sometimes analyzed samples from the same individual captured on different days within the same trapping session. Our trapping and handling methods conformed to guidelines approved by the American Society of Mammalogists (Sikes et al. 2011).

The fecal samples were cataloged and within 2 months were sent to the Composition Analysis Laboratory. Methods for microhistological analysis followed Hansen et al. (1973). An individual microscope slide was prepared for each sample by grinding the pellets over a 1-mm screen and placing the cleared particles on a slide. Twenty fields were read from each sample slide using a phase-contrast microscope at $100 \times$ magnification. Plant items on the slides were identified by matching their epidermal patterns with those of plant tissues in a reference slide collection containing the plant species observed on the sites. All plant parts were identified to the lowest taxon possible. The percent frequency was computed for all items present in the sample by comparing the number of fields in which an item occurred to the total number of fields examined. Density for each species detected was determined by referring to a conversion table developed by the Composition Analysis Laboratory, and percent relative density was calculated by taking the percent of an individual density divided by total density. Percent relative density for each item is considered to be a reasonable estimate of its dry-weight contribution to the diet.

Bait consisted of a commercial livestock feed containing corn, oats, barley, and molasses. Prebaiting sometimes resulted in bait residues in the fecal samples. We discarded sample results when bait composed $\geq 50 \%$ mean relative density. For samples containing $<50 \%$ bait, we calculated the percent mean relative density of the nonbait food items only.

\section{Evaluation of Diet Methodology}

The protected status of the Mohave ground squirrel precluded using stomach content analysis to compare with microhistological analysis. However, in a diet study of the Piute ground squirrel (Urocitellus mollis), Van Horne et al. (1998) found a high degree of similarity (86\%-92\% similarity index) in triplicates of fecal samples and in stomach content-feces comparisons. They concluded that fecal analysis using a microhistological technique was a reasonably reliable method to determine food habits for that species. Similar studies have found a close correspondence between diet estimates from stomach contents and fecal samples in Columbian ground squirrels (Urocitellus columbianus) and black-tailed prairie dogs (Cynomys ludovicianus) (Wydeven and Dahlgren 1982, Harestad 1986).

\section{Comparisons of Sample Groups}

To determine whether fecal samples from juveniles and adults or from males and females should be grouped in characterizing the diet, we calculated similarity indices following the method of Anthony and Smith (1977):

$$
S I=\sum_{i=1}^{n} Y_{i}
$$

In this equation, the similarity index $(S I)$ is calculated as the sum of the lower of 2 mean relative density values $\left(Y_{i}\right)$ for each shared food item, with $n$ as the total number of items. We compared similarity indices for groups of animals of different age and sex captured within the same trapping session. We also calculated similarity indices for randomly separated groups of same-age as well as same-sex individuals from the same trapping session to evaluate the inherent variation within a particular group.

\section{Vegetation Sampling}

Beginning in 1989, we sampled herbaceous species composition and aboveground standing crop of annual herbs in late May to early June when most herbaceous vegetation was at 
TABLE 1. Overall Mohave ground squirrel diet, by major category, at 4 study sites combined in the Coso Range, Inyo County, California, during 1988-1996.

\begin{tabular}{lcc}
\hline Diet category & $\begin{array}{c}\% \\
\text { Relative } \\
\text { density }\end{array}$ & $\begin{array}{c}\text { \% Frequency } \\
\text { among samples } \\
(n=754)\end{array}$ \\
\hline Shrub leaves and stems & 39.8 & 78.8 \\
Perennial forb leaves & 13.0 & 37.7 \\
Annual forb leaves & 21.1 & 66.0 \\
Flowers, pollen, seeds & 20.3 & 53.2 \\
Grass leaves & 2.5 & 25.2 \\
Arthropods & 2.6 & 33.7 \\
Other (roots, fungi, bone) & 0.7 & 6.9 \\
ToTAL & 100.0 & \\
\hline
\end{tabular}

or nearing its full growth. At alternating trap stations on alternating lines of traps, we randomly selected pairs of $0.09-\mathrm{m}^{2}$ plots representing between- and under-shrub microsites, yielding 100 plot pairs per site. Within each plot, all herbaceous species were recorded. Annuals were clipped at ground level and plant material was collected in a paper container, air-dried at $40{ }^{\circ} \mathrm{C}$ to a constant weight, and then weighed. Clipping was not performed on perennial grasses or herbs at any time. To represent overall standing crop, the mean of between- and under-shrub plots was calculated for each year and site and expressed as $\mathrm{kg} \cdot \mathrm{ha}^{-1}$.

In 1994 we sampled shrub species composition, cover, and frequency by a line intercept method. Ten alternating lines of traps were selected on each site. On each line, alternating 25-m sampling units were established, for a total of 100 units for each site. The species and length of intercept were recorded to the nearest $10 \mathrm{~cm}$ for each individual shrub intercepted, thus providing frequency and cover values by species. Percent cover for each shrub species was calculated by dividing the total length of its intercept by the total distance sampled at each site.

\section{Visual Observations of Foraging}

Mohave ground squirrels were rarely seen during trapping sessions because of their wary behavior and cryptic coloration. However, we observed foraging activity during radiotelemetry studies at site 3 in 1995-1997, when a number of radio-collared individuals became habituated to human presence. When we observed them feeding, we noted the identity of the animal, the date and time, and the food item being consumed.
TABLE 2. Overall percent mean relative density and frequency of 8 principal plant taxa in the Mohave ground squirrel diet at 4 sites combined in the Coso Range, Inyo County, California, calculated from all samples $(n=754)$ over 9 years.

\begin{tabular}{lcc}
\hline Food item & $\begin{array}{c}\text { \% Mean } \\
\text { relative density }\end{array}$ & $\begin{array}{c}\% \\
\text { Frequency }\end{array}$ \\
\hline $\begin{array}{l}\text { Krascheninnikovia } \\
\quad \text { lanata leaves }\end{array}$ & 18.2 & 44.0 \\
$\begin{array}{l}\text { Astragalus lentiginosus } \\
\quad \text { leaves }\end{array}$ & 12.6 & 35.2 \\
Grayia spinosa leaves & 11.9 & 28.0 \\
$\begin{array}{l}\text { Atriplex spp. leaves } \\
\text { Gilia } \text { sp./Linanthus sp. }\end{array}$ & 7.4 & 47.1 \\
$\quad$ leaves and seeds & 7.4 & 34.3 \\
$\begin{array}{l}\text { Lupinus odoratus } \\
\quad \text { leaves, pods, and } \\
\quad \text { seeds }\end{array}$ & 5.4 & 19.4 \\
Asteraceae leaves, & & \\
$\quad$ flowers, and seeds & & \\
$\quad$ Eriogonum spp. leaves & 4.5 & 20.7 \\
ToTAL & 3.4 & 11.1 \\
\hline
\end{tabular}

\section{RESULTS}

\section{Overview of Diet Composition}

We analyzed a total of 754 fecal samples from 1988 to 1996. Microhistological analysis identified 77 distinct food items representing approximately 50 plant taxa in 24 families and including other material such as fungus, bones, and arthropod fragments (Appendix 1).

The Mohave ground squirrel diet was strongly dominated by foliage, which made up $76.4 \%$ relative density (Table 1 ). Leaves and stems of shrubs were the most important components in the diet, accounting for almost $40 \%$ relative density and appearing in over three-fourths of all samples analyzed. Forb leaves composed $34.1 \%$ of the total diet and were recorded in $88 \%$ of all samples; annual forbs contributed $21.1 \%$ relative density and perennial forbs $13.0 \%$. Plant reproductive structures-including flowers, pollen, and seeds-totaled $20.3 \%$ of the diet (frequency $53.2 \%$ ). Because much of the flower and pollen material could not be identified to family and much of the flower and seed identified as Asteraceae could not be identified to genus, the relative contribution of flowers and seeds from shrubs versus forbs could not be determined.

Despite the large number of food items recorded, only 8 plant taxa contributed almost $71 \%$ of the Mohave ground squirrel diet across all sites, years, and seasons (Table 2). Leaves 
TABLE 3. Comparison of similarity indices for groups of Mohave ground squirrels based on age and gender within a site and sampling period.

\begin{tabular}{|c|c|c|c|c|}
\hline Comparison & $\begin{array}{c}\text { Number of } \\
\text { comparisons }\end{array}$ & $\begin{array}{c}\text { Samples } \\
\text { compared }\end{array}$ & $\begin{array}{c}\text { Mean } \\
\text { similarity index }\end{array}$ & Range \\
\hline Juvenile female vs. juvenile male & 10 & 102 vs. 97 & 67.7 & $55.4-89.4$ \\
\hline Adult female vs. adult male & 9 & 97 vs. 71 & 73.0 & $53.1-87.5$ \\
\hline Adult vs. juvenile & 6 & 54 vs. 109 & 79.0 & $69.7-92.0$ \\
\hline Same age and sex, randomly divided & 7 & 39 vs. 38 & 73.0 & $52.0-88.6$ \\
\hline
\end{tabular}

TABle 4. Annual herbaceous standing crop for each study site, with precipitation during the preceding winter (1 October-31 March) and data on Mohave ground squirrel reproduction.

\begin{tabular}{lccccccccc}
\hline & \multicolumn{7}{c}{ Annual herbaceous standing crop $\left(\mathrm{kg} \cdot \mathrm{ha}{ }^{-1}\right)$} \\
\cline { 2 - 10 } Site number & 1988 & 1989 & 1990 & 1991 & 1992 & 1993 & 1994 & 1995 & 1996 \\
\hline 1 & N/A & 65 & $<0.1$ & 334 & 517 & 635 & 11 & 753 & 43 \\
2 & N/A & 11 & $<0.1$ & 301 & 334 & 344 & 22 & 226 & 11 \\
3 & N/A & 11 & $<0.1$ & 441 & 603 & 603 & 65 & 474 & 22 \\
4 & N/A & 22 & $<0.1$ & 194 & 248 & 248 & 22 & 248 & 11 \\
Precipitation (mm) & 90.9 & 62.5 & 13.7 & 88.4 & 199.9 & 213.9 & 54.1 & 233.7 & 77.2 \\
Reproduction & Yes & No & No & Yes & Yes & Yes & No & Yes & No \\
\hline
\end{tabular}

from 3 species of chenopod shrubs (winterfat, spiny hopsage, and saltbush) made up $>37 \%$ of the diet. Leaves, flowers, and seeds from 5 herbaceous taxa contributed $33 \%$ of the diet. These were the perennial freckled milkvetch (Astragalus lentiginosus, Fabaceae) and the annual Mojave lupine (Lupinus odoratus, Fabaceae); annual species of the closely related genera Gilia or Linanthus (Polemoniaceae); composites or members of the sunflower family (Asteraceae); and buckwheat (Eriogonum spp., Polygonaceae). These 8 food items appeared with frequencies ranging from $11.1 \%$ to $47.1 \%$.

\section{Comparisons of Sample Groups}

Table 3 presents the results of similarity index comparisons between groups of Mohave ground squirrels based upon age and sex. Means and ranges were very similar in comparisons of adults with juveniles and males with females. Seven comparisons were also made of randomly divided groups of same-age and same-sex animals within a given trapping session. This analysis yielded a mean similarity index of $73 \%$, with a range of $52.0 \%-88.6 \%$. Because these results showed no substantial difference between males and females or juveniles and adults within a given trapping session, all such samples were combined for further comparison between sites and seasons.

\section{Influence of Winter Rainfall on Food Resources and Reproduction}

Winter precipitation played a critical role in the productivity of annual herbaceous plants on our study sites. During 1988-1996, winter precipitation varied from $14 \mathrm{~mm}$ to $214 \mathrm{~mm}$, and herbaceous standing crop ranged over nearly 3 orders of magnitude, from $<0.1 \mathrm{~kg} \cdot \mathrm{ha}^{-1}$ to $753 \mathrm{~kg} \cdot \mathrm{ha}^{-1}$ (Table 4). Mohave ground squirrel reproduction was closely dependent upon annual herbaceous productivity. Reproduction occurred only following winters with precipitation $>80 \mathrm{~mm}$, when herbaceous standing crop was $>100 \mathrm{~kg}$. $\mathrm{ha}^{-1}$. In the 4 years with winter precipitation $<80 \mathrm{~mm}$, standing crop was well below $100 \mathrm{~kg} \cdot \mathrm{ha}^{-1}$ in both between- and undershrub plots and there was reproductive failure in Mohave ground squrrels. Study years were henceforth divided into "dry" (winter rainfall $<80 \mathrm{~mm}$ ) and "wet" (winter rainfall $\geq 80 \mathrm{~mm}$ ) years.

\section{Influence of Season and Rainfall on Mohave Ground Squirrel Diet}

Mohave ground squirrel diet differed between spring and summer sampling periods. Diet also varied in response to changes in the availability of annual herbaceous forage that were in turn correlated with rainfall amounts over the preceding winter. We analyzed dietary 
TABLE 5. Plant taxa, by season and rainfall year, contributing $\geq 5 \%$ mean relative density in the diet of the Mohave ground squirrel in the Coso Range, Inyo County, California. Wet years (1988, 1991, 1992, 1993, and 1995) were defined as $\geq 80 \mathrm{~mm}$ rainfall during the preceding winter (1 October-31 March), while dry years $(1989,1990,1994$, and 1996) were defined as $<80 \mathrm{~mm}$ rainfall for the same period.

\begin{tabular}{|c|c|c|c|c|c|c|}
\hline \multirow[b]{2}{*}{ Food items } & \multicolumn{3}{|c|}{ Spring } & \multicolumn{3}{|c|}{ Summer } \\
\hline & $\begin{array}{l}\text { All years } \\
(n=9)\end{array}$ & $\begin{array}{l}\text { Wet years } \\
\quad(n=5)\end{array}$ & $\begin{array}{c}\text { Dry years } \\
(n=4)\end{array}$ & $\begin{array}{c}\text { All years } \\
(n=9)\end{array}$ & $\begin{array}{l}\text { Wet years } \\
\quad(n=5)\end{array}$ & $\begin{array}{c}\text { Dry years } \\
(n=4)\end{array}$ \\
\hline Sample size & 338 & 140 & 198 & 416 & 329 & 87 \\
\hline \multicolumn{7}{|l|}{ Leaves } \\
\hline \multicolumn{7}{|l|}{ Shrubs } \\
\hline Atriplex spp. & 12.8 & 8.3 & 15.9 & 3.1 & 2.5 & 5.5 \\
\hline Grayia spinosa & 25.4 & 6.3 & 39.0 & 0.9 & 0.1 & 4.0 \\
\hline Krascheninnikovia lanata & 10.4 & 9.0 & 11.3 & 24.6 & 29.6 & 5.8 \\
\hline Total, shrub leaves & 48.6 & 23.6 & 66.2 & 28.6 & 32.2 & 15.3 \\
\hline \multicolumn{7}{|l|}{ Forbs } \\
\hline Astragalus lentiginosus & 17.1 & 23.7 & 12.3 & 9.0 & 8.0 & 12.7 \\
\hline Gilia and Linanthus & 6.9 & 9.5 & 5.1 & 9.7 & 4.6 & 28.7 \\
\hline Lupinus odoratus & 4.2 & 8.2 & 1.3 & 0.7 & 0.9 & 0.1 \\
\hline Eriogonum spp. & 4.4 & 8.7 & 1.4 & 0.6 & 0.5 & 1.1 \\
\hline Eremalche exilis & 0.0 & 0.1 & 0.0 & 4.5 & 5.7 & 0.0 \\
\hline Total, forb leaves & 35.0 & 50.2 & 20.9 & 24.6 & 19.7 & 42.6 \\
\hline \multicolumn{7}{|l|}{ Grass } \\
\hline Bromus spp. & 0.6 & 0.3 & 0.9 & 2.5 & 1.0 & 8.0 \\
\hline TOTAL, LEAVES & 84.2 & 74.1 & 87.2 & 55.7 & 52.9 & 65.9 \\
\hline \multicolumn{7}{|l|}{ Flowers and seeds } \\
\hline \multicolumn{7}{|l|}{ Shrubs } \\
\hline Larrea tridentata seeds & 0.1 & 0.1 & 0.1 & 3.3 & 3.5 & 2.4 \\
\hline Lycium spp. seeds & 0.5 & 0.0 & 0.8 & 2.0 & 0.6 & 6.9 \\
\hline Opuntia fruits and seeds & 0.0 & 0.0 & 0.0 & 4.4 & 5.6 & 0.0 \\
\hline Total, shrub seeds & 0.6 & 0.1 & 0.9 & 9.7 & 9.7 & 9.3 \\
\hline \multicolumn{7}{|l|}{ Forbs } \\
\hline Composite flowers and seeds & 0.0 & 0.0 & 0.0 & 6.7 & 8.5 & 0.0 \\
\hline Legume seeds & 0.2 & 0.4 & 0.1 & 5.6 & 7.1 & 0.0 \\
\hline Total, forb flowers and seeds & 0.2 & 0.4 & 0.1 & 12.3 & 15.6 & 0.0 \\
\hline Other flowers and pollens & 4.6 & 5.1 & 0.2 & 2.7 & 2.8 & 0.8 \\
\hline TOTAL, FLOWERS AND SEEDS & 5.4 & 5.6 & 1.2 & 24.7 & 28.1 & 10.1 \\
\hline GRAND TOTAL & 89.6 & 79.7 & 88.4 & 80.4 & 81.0 & 76.0 \\
\hline
\end{tabular}

data separately for dry and wet years. Just 15 food items made up $\geq 5 \%$ mean relative density in at least one season in either dry or wet years (Table 5).

In spring, Mohave ground squirrel diets were strongly dominated by foliage from a few species of shrubs and forbs. Leaf material from just 3 chenopod shrub taxa (winterfat, spiny hopsage, and saltbush) plus a perennial forb (freckled milkvetch) made up $65.7 \%$ of mean relative density. Leaf material from 3 annual forb taxa (Gilia/Linanthus, Lupinus odoratus, Eriogonum spp.) contributed another $15.5 \%$. However, their proportions differed in dry and wet years. In spring of dry years, Mohave ground squirrels relied primarily on foliage from the 3 chenopod shrubs, which composed $>66 \%$ of the diet; spiny hopsage alone made up $39 \%$ mean relative density, while the contribution from freckled milkvetch and the other 3 forbs was much reduced. In the springs of wet years, shrub leaves made up only $23.6 \%$ of the diet, while leaf material from the 4 forb taxa contributed $50.1 \%$; freckled milkvetch foliage alone accounted for almost one-quarter of the total.

In summer, foliage still made up over onehalf of the diet, with winterfat leaves the largest single component at $24.6 \%$ relative density. Leaf material from freckled milkvetch and Gilia/Linanthus contributed $18.7 \%$. Flowers and seeds were also important in summer, composing almost one-quarter of the diet. Most of the seeds were either Asteraceae or Fabaceae. Again, the proportion differed in dry and wet years. In the summers of dry years, over one-half of the diet was derived from herbaceous leaf material, mostly from freckled 
TABLE 6. Food items observed being consumed by radio-collared Mohave ground squirrels at site 3 during $1995-1997$. Spring observations spanned the period 22 February-27 April, while summer observations were made during the period 3 May-2 July.

\begin{tabular}{|c|c|c|c|c|}
\hline \multirow[b]{2}{*}{ Food item } & \multicolumn{2}{|c|}{ Observations } & \multicolumn{2}{|c|}{$\begin{array}{l}\text { Mohave ground } \\
\text { squirrels observed }\end{array}$} \\
\hline & Spring & Summer & Spring & Summer \\
\hline \multicolumn{5}{|l|}{ Shrubs } \\
\hline Grayia spinosa flowers, leaves & 4 & 2 & 3 & 2 \\
\hline Lycium andersonii leaves, stems & 1 & 2 & 1 & 2 \\
\hline Lycium cooperi leaves & 7 & 3 & 4 & 3 \\
\hline Tetradymia spinosa & 1 & & 1 & \\
\hline Yucca brevifolia fruits, seeds & & 18 & & 13 \\
\hline \multicolumn{5}{|l|}{ Forbs } \\
\hline Amsinckia tessellata leaves, flowers, fruits & 5 & 3 & 3 & 2 \\
\hline Chaenactis sp. leaves, flowers & 2 & & 1 & \\
\hline Cryptantha pterocarya fruits & 1 & & 1 & \\
\hline Leptosyne (= Coreopsis) bigelovii & 1 & 2 & 1 & 2 \\
\hline Lessingia glandulifera flowers & & 2 & & 2 \\
\hline Lupinus odoratus leaves & 1 & & 1 & \\
\hline Malacothrix glabrata flowers & 2 & & 1 & \\
\hline Phacelia sp. leaves & 1 & & 1 & \\
\hline Stephanomeria sp. & & 1 & & 1 \\
\hline \multicolumn{5}{|l|}{ Grasses } \\
\hline Bromus sp. leaves & 2 & & 1 & \\
\hline Stipa sp. leaves & 1 & & 1 & \\
\hline TOTAL OBSERVATIONS & 29 & 33 & 20 & 28 \\
\hline
\end{tabular}

milkvetch and Gilia/Linanthus. Shrub material was also important, especially foliage from chenopod shrubs and seeds from creosote bush (Larrea tridentata) and boxthorn (Lycium spp.). In wet summers, herbaceous leaves made up only $20.7 \%$ of Mohave ground squirrel diet. Winterfat leaves were the most important single food item at $29.6 \%$ relative density, while flowers and seeds from both shrubs and forbs composed another $28.1 \%$ of the diet.

\section{Visual Observations of Foraging}

At site 3 we observed radio-collared Mohave ground squirrels feeding on plant material from 16 different taxa (Table 6). In spring, squirrels were most frequently seen foraging on spiny hopsage, Cooper's boxthorn, and desert fiddleneck (Amsinckia tessellata). In summer, squirrels were most often observed in Joshua trees. We also saw squirrels feeding on annual composites, such as coreopsis (Leptosyne [= Coreopsis $]$ ), desert dandelion (Malacothrix), lessingia (Lessingia), and wirelettuce (Stephanomeria); in addition, some Mohave ground squirrels were observed with deep yellow staining around their mouths, matching the pollen and flower color of coreopsis, one of the most common spring annuals.

\section{Discussion}

\section{Role of Perennial Foliage}

Mohave ground squirrels at our study sites primarily consumed foliage, which made up three-quarters of the total diet. Just over $50 \%$ of the diet consisted of leaves from 4 perennial taxa: the herb freckled milkvetch and the shrubs winterfat, spiny hopsage, and saltbush. These perennial food sources were particularly important when annual forbs were limited, especially in early spring and during dry years. However, each appears to play a distinctive role in the diet of the Mohave ground squirrel.

Freckled milkvetch breaks dormancy and produces new foliage each year, even under the most extreme drought conditions, making it a more reliable food source than most annual forbs. Astragalus and the closely related Oxytropis have also been reported as major components of the diet in Richardson's ground squirrel (Urocitellus richardsonii) in Colorado (Hansen and Ueckert 1970) and in Arctic ground squirrel (Urocitellus parryii) in Yukon (McLean 1985), despite the fact that Astragalus and Oxytropis species (collectively known as locoweed) are toxic to livestock on rangelands of the western United States (James and Nielson 1988). The behavioral or 
physiological adaptations that allow Mohave ground squirrels to consume milkvetch foliage without suffering adverse effects are unknown.

In the Coso Range, the foliage of spiny hopsage and winterfat appear to be critical components of the Mohave ground squirrel diet. Spiny hopsage was by far the most important food item for Mohave ground squirrels in spring. Like freckled milkvetch, it breaks dormancy relatively early, and its spring growth is high in nutrition. The crude protein content of spiny hopsage leaves $(18 \%)$ is reported to be higher than that of most other shrubs within its range (Krysl et al. 1984). Spiny hopsage is heavily utilized by livestock, wild ungulates, and blacktailed jackrabbits (Lepus californicus), especially from late winter through spring (Shaw 1992).

In contrast to the summer-deciduous spiny hopsage, winterfat is evergreen, thus providing a potential food source when annuals and deciduous shrubs are limited. Winterfat initiates leaf growth in late spring, and the new foliage may be a preferred food item, which could explain its high contribution to the summer diet of the Mohave ground squirrel.

Three saltbush species (shadscale, allscale, and fourwing saltbush) occurred on our study sites, but microhistological analysis could not distinguish the species. Saltbush was utilized more in spring than in summer by Mohave ground squirrels. Saltbush leaves averaged $<8 \%$ in the overall diet, suggesting that it is less preferred than spiny hopsage and winterfat. This could be due to the high salt content in saltbush leaves.

\section{Role of Annual Plants in Mohave Ground Squirrel Reproduction}

The Mojave Desert is noted for its highly diverse annual flora (Jennings 2001). Winter precipitation plays a critical role in germination and growth of Mojave Desert annual plants (Beatley 1974). Our data showed that Mohave ground squirrel reproduction occurred only when winter rainfall was $>80 \mathrm{~mm}$ and the resulting standing crop of herbaceous annuals was $>100 \mathrm{~kg} \cdot \mathrm{ha}^{-1}$. Thus, Mohave ground squirrel reproduction is closely associated with adequate winter rainfall and the resulting spring growth of annuals.

\section{Little-utilized Food Resources}

Although 77 distinct food items were detected in the 754 fecal samples reported here, only about 15 plant taxa contributed significantly to the Mohave ground squirrel diet (Appendix 1). Squirrels consumed little or no material from many shrub taxa that were common on our study sites, including white bursage (Ambrosia dumosa), cheesebush, goldenhead, and Cooper's goldenbush (Ericameria cooperi). Squirrels consumed little of the abundant native forb genera Camissonia (Onagraceae), Cryptantha (Boraginaceae), Mentzelia (Loasaceae), and Phacelia (Boraginaceae), which typically were among the most frequently occurring annual genera on the study sites. They consumed minimal amounts of grass, despite the fact that the nonnative genera Bromus and Schismus were always among the most frequently occurring annual genera and the native sixweeks fescue (Festuca octoflora) was abundant in some years. The native bunchgrasses in the genera Stipa and Poa were consumed little, if at all.

The nonnative forb redstem filaree (Erodium cicutarium) was present, especially at sites 1 and 2 , but was consumed very little (and then primarily during dry years). We conclude that even when relatively common, this annual species is not a preferred food of the Mohave ground squirrel. The highly invasive Saharan mustard (Brassica tournefortii) was not present in our study area so its potential role in the Mohave ground squirrel diet is unknown.

\section{Visual Observations of Items Consumed}

Our visual observations of feeding Mohave ground squirrels were consistent with the results of microhistological analysis with 2 noteworthy exceptions. First, we never saw Mohave ground squirrels feeding on winterfat. Because winterfat is densely branched, it may have been difficult to observe squirrels feeding in or around winterfat shrubs.

The second discrepancy concerned Joshua tree fruits and seeds. While more than half of our May and June observations consisted of Mohave ground squirrels foraging in Joshua trees, fruit and seed material from this species made up $<1 \%$ of mean relative density in fecal samples analyzed. However, the large number of observations may be explained by the high visibility of animals actively foraging in Joshua trees. Zembal and Gall (1980) also made many observations of Mohave ground squirrels foraging on Joshua tree fruits, then making repeated trips to 
their burrows. This strongly suggested seed caching behavior.

Recht (1977) studied foraging activities at a site in the southern part of the range. In 2400 visual observations of 8 radio-collared individuals, Recht recorded Mohave ground squirrels feeding on 11 plant taxa, primarily the native species Cooper's boxthorn, coreopsis, and fiddleneck, as well as the nonnative Russian thistle (Salsola tragus). He concluded that Mohave ground squirrels appeared to select plant species with the highest water content. Our observations of feeding behavior were reasonably consistent with those of Recht. We saw Mohave ground squirrels consume 5 of the 11 plant taxa reported by Recht; the other 6 were confirmed by microhistological analysis. However, while boxthorn, coreopsis, and fiddleneck composed $39 \%$ of our visual observations, they constituted no more than $10 \%$ of overall mean relative density in fecal samples, suggesting that foraging behavior on some food items may be more readily detectable than on others and that microhistological analysis may present a more complete picture of the Mohave ground squirrel diet.

\section{Diet of Mohave Ground Squirrels Elsewhere in Range}

Most of the Mohave ground squirrel range lies to the south and southeast of the Coso Range at lower elevation and with lower average precipitation. Creosote bush scrub is the dominant vegetation over much of the range, areas with high proportions of spiny hopsage and winterfat are relatively uncommon, and productivity of annual forbs is generally less than in the Coso study sites. As a result, caution is appropriate in generalizing about the Mohave ground squirrel diet elsewhere in its range.

\section{Comparison with Other Aridland Ground Squirrels}

The Piute ground squirrel (Urocitellus mollis)—formerly Townsend's ground squirrel-inhabits the shrubsteppe of the Great Basin and Snake River Valley. Its diet has been studied in southwestern Idaho where habitats dominated by native shrubs and perennial bunchgrasses are being replaced by exotic annual grasses and forbs (Yensen and Quinney 1992). Major native food items include Sandberg bluegrass (Poa sandbergii), a native perennial bunchgrass, and shrub foliage from winterfat and big sagebrush (Artemisia tridentata) (Van Horne et al. 1998). Yensen and Quinney (1992) reported that Piute ground squirrels at their study sites also consumed significant amounts of exotic annuals, particularly cheatgrass (Bromus tectorum) and Russian thistle. However, Yensen et al. (1992) found that Piute ground squirrel burrow densities were negatively correlated with cheatgrass and other exotic annuals in the vegetation communities that they sampled. Van Horne et al. (1998) concluded that winterfat and, to a lesser extent, big sagebrush provided a relatively reliable food source under drought conditions, and that habitats dominated by annuals were unlikely to sustain viable populations of Piute ground squirrels. Thus, in comparing the Piute ground squirrel with the Mohave ground squirrel, both appear to utilize shrub foliage extensively. The former, however, is highly dependent on perennial bunchgrasses when available and will also consume large amounts of cheatgrass and other exotic annuals at sites dominated by these invasive species. Mohave ground squirrels are able to rely on native chenopod shrubs and annual forbs, thus avoiding the need to consume exotic grasses.

The round-tailed ground squirrel (Xerospermophilus tereticaudus) is closely related to the Mohave ground squirrel. It inhabits the eastern Mojave, Colorado, and Sonoran deserts (Ernest and Mares 1987), which differ from the western Mojave Desert in receiving significant summer rainfall and supporting a distinctive "summer annual" flora. In Arizona, green vegetation constitutes the majority of the round-tailed ground squirrel diet, along with insects and seeds, especially those of creosote bush and cactus (Drabek 1970). There has been no diet study of round-tailed ground squirrels in the California deserts, so it is not clear whether chenopod shrubs or native forbs are important there.

\section{Future Research}

Our findings raise a number of questions regarding the Mohave ground squirrel diet. First, the diet of the Mohave ground squirrel in the central, southern, and eastern portions of its range should be compared with the results presented here. Second, it would be of interest to investigate the mechanism underlying the association between reproduction and herbaceous annual plant production in the diet of the Mohave ground squirrel, in 
particular the relative importance of energy versus moisture content as limiting factors. Third, further analysis is needed to determine the relative importance of individual saltbush species in the Mohave ground squirrel diet. Fourth, further investigation could help to clarify how Mohave ground squirrels can consume milkvetch foliage, apparently without adverse effects. Finally, the potential importance of creosote bush should be investigated. Our study sites contained little creosote bush, but much of the geographic range of the Mohave ground squirrel is dominated by this species. Creosote bush usually produces large quantities of seeds in late May, when Mohave ground squirrels are preparing for dormancy.

\section{Conservation Implications}

Since the Mohave ground squirrel occurs only within a small area of the western Mojave Desert and is threatened by habitat loss and degradation, it is important to identify and conserve lands with the food resources needed to support persistent populations. This is particularly urgent because the species occupies a region of high priority for the siting of renewable energy facilities. This study showed that several perennial plant species, especially spiny hopsage and winterfat, play an important role in the Mohave ground squirrel diet, especially in the spring and in drought periods when annual plants are scarce. Habitats supporting some minimum density of these plant species are of high value for conservation. The importance of annual plant productivity for Mohave ground squirrel reproduction indicates that areas with abundant native forbs should also be a high conservation priority. Our data suggest that sites dominated by the invasive nonnative filaree, brome grasses, and Russian thistle are of less value to Mohave ground squirrels. This is consistent with the observation of Lohr et al. (2013) that sites with higher percentages of exotic annual plant cover tended to have low densities of southern Idaho ground squirrel (Urocitellus endemicus) burrows.

Anthropogenic climate change may adversely affect forage plants important to the persistence of Mohave ground squirrel populations. Climate models project that the deserts of the southwestern United States will experience a progressively warmer and more arid climate over the 21st century (Seager et al. 2007, Diffenbaugh et al. 2008). Winterfat and spiny hopsage are primarily Great Basin species adapted to lower temperatures for germination and growth than more typical Mojave Desert species such as creosote bush. There is evidence that spiny hopsage in particular is quite sensitive to drought. From 1975 to 2001 spiny hopsage decreased an average of $80.1 \%$ in 32 permanent study plots at the Nevada Test Site in southern Nevada (Webb et al. 2003). This drastic decline was attributed to the severe drought episode of 1989-1991. Future climate change with higher temperatures and more limited and erratic rainfall is likely to reduce the distribution and abundance of winterfat and spiny hopsage in the Mojave Desert. This could further restrict and fragment the geographic range of the Mohave ground squirrel.

\section{ACKNOWLEDGMENTS}

The authors are deeply grateful to J. Hopkins, formerly of McClenahan and Hopkins Associates, who was instrumental in planning and obtaining funding for the Coso Grazing Exclosure Mohave Ground Squirrel Study. This research was funded primarily by California Energy Company, Inc. (now Coso Operating Company LLC), with additional support provided by California Department of Fish and Game, Naval Air Weapons Station China Lake, McClenahan and Hopkins Associates, and the Bureau of Land Management. T. Foppe of the Composition Analysis Laboratory, Fort Collins, Colorado, carried out the fecal analysis. This work was conducted under authority of a Memorandum of Understanding issued by the California Department of Fish and Game (CDFG). We thank J. Gustafson of the CDFG for his support in permitting this research effort. T. Tarifa, E. Yensen, and 2 anonymous reviewers provided comments that greatly improved earlier versions of this manuscript. We are particularly grateful for the professional expertise of our colleague J. Harris, who collaborated on the trapping and radiotelemetry, and the many technicians who assisted us with the trapping, radiotelemetry, and vegetation surveys, particularly J. Randall, P. Scarry, and A. Stanton, who also helped with data analysis.

\section{Literature Cited}

Anthony, R.G., AND N.S. Smith. 1977. Ecological relationships between mule deer and white-tailed deer 
in southeastern Arizona. Ecological Monographs 47:255-277.

Bartholomew, G.A., And J.W. Hudson. 1960. Aestivation in the Mohave ground squirrel Citellus mohavensis. Bulletin of the Museum of Comparative Zoology 124:193-208.

Beatley, J.C. 1974. Phenological events and their environmental triggers in Mojave Desert ecosystems. Ecology 55:856-863.

BEst, T.L. 1995. Spermophilus mohavensis. American Society of Mammalogists, Mammalian Species 509:1-7.

Diffenbaugh, N.S., F. Giorgi, and J.S. Pal. 2008. Climate change hotspots in the United States. Geophysical Research Letters 35:L16709.

DrabeK, C.M. 1970. Ethoecology of the round-tailed ground squirrel, Spermophilus tereticaudus. Doctoral dissertation, University of Arizona, Tucson, AZ. 119 pp. University Microfilms International, Ann Arbor, MI; AAT 7023665.

Ernest, K.A., And M.A. Mares. 1987. Spermophilus tereticaudus. Mammalian Species 274:1-9.

Gustafson, J.R. 1993. A status review of the Mohave ground squirrel (Spermophilus mohavensis). California Department of Fish and Game, Nongame Bird and Mammal Section, Sacramento, CA. 104 pp. + appendixes.

Hansen, R.M., D.G. Peden, and R.W. Rice. 1973. Discerned fragments in feces indicate diet overlap. Journal of Range Management 26:103-105.

Hansen, R.M., AND D.N. UECKerT. 1970. Dietary similarity of some primary consumers. Ecology 51:640-648.

Harestad, A.S. 1986. Food habits of Columbian ground squirrels: a comparison of stomach and fecal samples. Murrelet 67:75-78.

Helgen, K.M., F.R. Cole, L.E. Helgen, and D.E. WilSON. 2009. Generic revision in the Holarctic ground squirrel genus Spermophilus. Journal of Mammalogy 90:270-305.

James, L.F., AND D.B. Nielson. 1988. Locoweed: assessment of the problem on western U.S. rangelands. Pages 171-180 in L.F. James, M.H. Ralphs, and D.B. Nielson, editors, The ecology and economic impact of poisonous plants on livestock production. Westview Press, Boulder, CO.

Jennings, W.B. 2001. Comparative flowering phenology of plants in the western Mojave Desert. Madroño 48:162-171.

Krysh, L.J., B.F. Sowell, M.E. Hubbert, G.E. Plumb, T.K. JeWEtT, M.A. Smith, and J.W. WagGoner. 1984. Horses and cattle grazing in the Wyoming Red Desert. II. Dietary quality. Journal of Range Management 37:252-256.

Leitner, P., AND B.M. Leitner. 1998. Coso Grazing Exclosure Monitoring Study. Mohave Ground Squirrel Study, Coso Known Geothermal Resource Area, Major Findings, 1988-1996. Final Report. 42 pp. + appendix.

Lohr, K., E. Yensen, J.C. Munger, and S.J. Novak. 2013. Relationship between habitat characteristics and densities of southern Idaho ground squirrels. Journal of Wildlife Management 77:983-993.
MCLEAN, I.G. 1985. Seasonal patterns and sexual differences in the feeding ecology of arctic ground squirrels (Spermophilus parryii plesius). Canadian Journal of Zoology 63:1298-1301.

Recht, M.A. 1977. The biology of the Mohave ground squirrel, Spermophilus mohavensis; home range, daily activity, foraging and weight gain and thermoregulatory behavior. Doctoral dissertation, University of California, Los Angeles, CA. 125 pp. Available from: University Microfilms International, Ann Arbor, MI; AAT 7801724.

Sawyer, J.O., T. Keeler-Wolf, and J.M. Evens. 2009. A manual of California vegetation. 2nd edition. California Native Plant Society, Sacramento, CA.

Seager, R., M. Ting, I. Held, Y. Kushnir, J. Lu, G. VecChi, H.-P. Huang, N. Harnik, A. Leetma, N.-C. Lau, C. LI, J. VELEZ, AND N. NAIK. 2007. Model projections of an imminent transition to a more arid climate in southwestern North America. Science 316:1181-1184.

SHaW, N.L. 1992. Germination and seedling establishment of spiny hopsage (Grayia spinosa [Hook.] Moq.). Doctoral dissertation, Oregon State University, Corvallis, OR. 185 pp. University Microfilms International, Ann Arbor, MI; AAT 9229768.

Sikes, R.S., W.L. Gannon, and the Animal Care and Use Committee of the American Society of MammaloGISTS. 2011. Guidelines of the American Society of Mammalogists for the use of wild mammals in research. Journal of Mammalogy 92:235-253.

Van Horne, B., R.L. Schooley, and P.B. Sharpe. 1998. Influence of habitat, sex, age, and drought on the diet of Townsend's ground squirrels. Journal of Mammalogy 79:521-537.

Webb, R.H., M.B. Murov, T.C. Esque, D.E. Boyer, L.A. DeFalco, D.F. Haines, D. Oldershaw, S.J. Scoles, K.A. Thomas, J.B. Blainey, and P.A. Medica. 2003. Perennial vegetation data from permanent plots on the Nevada Test Site, Nye County, Nevada. U.S. Geological Survey Open-File Report 03-336. 13 pp.

Wydeven, P.A., AND R.B. DAHLGREN. 1982. A comparison of prairie dog stomach contents and feces using a microhistological technique. Journal of Wildlife Management 46:1104-1108.

Yensen, E., And D.L. Quinney. 1992. Can Townsend's ground squirrels survive on a diet of exotic annuals? Great Basin Naturalist 52:269-277.

Yensen, E., D.L. Quinney, K. Johnson, K. Timmerman, and K. Steenhof. 1992. Fire, vegetation changes, and population fluctuations of Townsend's ground squirrels. American Midland Naturalist 128:299-312.

Zembal, R., ANd G. Gall. 1980. Observations on Mohave ground squirrels, Spermophilus mohavensis, in Inyo County, California. Journal of Mammalogy 61: 347-350.

Received 24 October 2014

Accepted 30 November 2016

Published online 21 February 2017 
ApPENDIX 1. All dietary items identified in Mohave ground squirrel fecal samples collected at 4 sites in the Coso Range, Inyo County, California, during 1988-1996. Mean relative density is given for all usable samples by season and by study site $(n=$ number of samples). Columns show mean value among all usable samples analyzed for each season and site and therefore sum to 100 .

\begin{tabular}{|c|c|c|c|c|c|c|c|c|}
\hline \multirow[b]{2}{*}{ Food item } & \multicolumn{2}{|c|}{ Site 1} & \multicolumn{2}{|c|}{ Site 2} & \multicolumn{2}{|c|}{ Site 3} & \multicolumn{2}{|c|}{ Site 4} \\
\hline & $\begin{array}{l}\text { Spring } \\
n=23\end{array}$ & $\begin{array}{c}\text { Summer } \\
n=55\end{array}$ & $\begin{array}{c}\text { Spring } \\
n=107\end{array}$ & $\begin{array}{c}\text { Summer } \\
n=115\end{array}$ & $\begin{array}{c}\text { Spring } \\
n=132\end{array}$ & $\begin{array}{c}\text { Summer } \\
n=133\end{array}$ & $\begin{array}{l}\text { Spring } \\
n=76\end{array}$ & $\begin{array}{c}\text { Summer } \\
n=113\end{array}$ \\
\hline \multicolumn{9}{|l|}{ Plant material } \\
\hline Ambrosia dumosa leaves & & 0.15 & 1.08 & 0.02 & & & & \\
\hline Astragalus lentiginosus leaves & 64.49 & 15.62 & 0.87 & 0.39 & 19.59 & 5.02 & 21.09 & 19.05 \\
\hline Atriplex leaves & 7.06 & 3.03 & 18.00 & 4.00 & 12.78 & 3.31 & 7.11 & 1.92 \\
\hline Baileya pleniradiata leaves & & 1.59 & 1.78 & 1.78 & 0.50 & & 0.06 & 0.06 \\
\hline Boraginaceae leaves & & 0.38 & 0.09 & 0.16 & 0.05 & 0.18 & 0.12 & \\
\hline Bromus leaves & 0.24 & 2.27 & 0.67 & 2.46 & 0.68 & 3.03 & 0.73 & 2.01 \\
\hline Camissonia campestris leaves & 0.14 & 0.10 & & 0.43 & 0.02 & 0.04 & & 0.04 \\
\hline Chenopodiaceae leaves & & & 0.23 & & & & & \\
\hline Chenopodiaceae seed & & & & 0.04 & & & & 0.72 \\
\hline $\begin{array}{l}\text { Centrostegia/Chorizanthe } \\
\text { seed }\end{array}$ & & 0.09 & & 1.84 & & 1.38 & & \\
\hline Chrysothamnus leaves & & & & 0.07 & & 0.41 & 0.04 & \\
\hline Composite flower & & 0.89 & & 1.40 & & 0.59 & & 1.54 \\
\hline Composite seed & & 4.96 & & 4.56 & 0.05 & 10.38 & & 1.44 \\
\hline Cryptantha leaves & 0.97 & 0.23 & 0.09 & & 0.01 & & 0.81 & 0.08 \\
\hline Cryptantha seed & & 0.05 & & 0.05 & & 0.28 & & 0.40 \\
\hline Descurainia pinnata leaves & & & 0.74 & & 0.15 & & & \\
\hline $\begin{array}{l}\text { Dichelostemma pulchella } \\
\text { leaves }\end{array}$ & & & & & 0.05 & & 0.11 & 0.56 \\
\hline Ephedra nevadensis stem & 0.36 & & 0.50 & 2.54 & 0.02 & 0.04 & 0.02 & 0.38 \\
\hline Eremalche exilis fruit & & 9.60 & & 0.38 & & & & \\
\hline Eremalche exilis leaves & & 32.21 & & 0.57 & 0.03 & 0.07 & 0.11 & 0.16 \\
\hline Eriastrum leaves & & 0.03 & & & & 0.19 & & 0.04 \\
\hline Eriogonum leaves & 5.26 & 0.14 & 10.58 & 1.44 & 2.94 & 0.61 & 8.07 & 0.38 \\
\hline Erodium cicutarium leaves & 0.47 & 0.06 & 3.64 & 0.01 & 0.10 & 1.99 & & 0.18 \\
\hline Erodium cicutarium seed & & 0.12 & & & & 0.02 & & 0.54 \\
\hline Festuca leaves & & & 0.06 & 0.12 & 0.03 & & 0.09 & \\
\hline Flower & 3.09 & 2.19 & 4.68 & 1.84 & 0.40 & 1.50 & 1.45 & 0.28 \\
\hline Fungus & & 1.38 & & 0.28 & & 1.13 & & 0.02 \\
\hline Gilia/Linanthus leaves & & 0.47 & 1.87 & 2.66 & 8.95 & 10.38 & 12.65 & 20.56 \\
\hline Gilia/Linanthus seed & & 0.43 & 0.22 & 0.21 & & 1.45 & & 3.88 \\
\hline Grayia spinosa leaves & 0.55 & & 14.21 & 1.02 & 31.26 & 1.18 & 38.61 & 0.85 \\
\hline $\begin{array}{l}\text { Gutierrezia microcephala } \\
\text { leaves }\end{array}$ & & & 0.25 & & & & & \\
\hline $\begin{array}{l}\text { Krascheninnikovia lanata } \\
\text { leaves }\end{array}$ & 2.48 & 2.33 & 21.32 & 42.04 & 6.43 & 24.47 & 4.17 & 17.81 \\
\hline Larrea tridentata leaves & & & 2.03 & 1.10 & & 0.08 & 0.35 & \\
\hline Larrea tridentata seed & & 0.10 & 0.13 & 6.31 & & 0.35 & 0.23 & 5.16 \\
\hline Layia glandulosa leaves & & 0.08 & & & & & & 0.12 \\
\hline Legume seed & 0.11 & 3.38 & 0.42 & 1.17 & 0.08 & 13.96 & 0.17 & 1.29 \\
\hline $\begin{array}{l}\text { Loeseliastrum matthewsii } \\
\text { leaves }\end{array}$ & & 0.90 & & 0.21 & & 0.05 & & 0.14 \\
\hline $\begin{array}{l}\text { Loeseliastrum matthewsii } \\
\text { seed }\end{array}$ & & 1.53 & & 1.20 & & 4.26 & & 1.98 \\
\hline Lomatium mohavense leaves & & 0.26 & 0.10 & & 0.12 & & 0.14 & \\
\hline Lupinus odoratus leaves & 10.30 & 0.96 & 1.70 & 0.32 & 7.39 & 1.09 & 0.21 & 0.58 \\
\hline Lycium leaves & & & 0.23 & 0.03 & 0.15 & 0.03 & 0.39 & 0.32 \\
\hline Lycium seed & & & 0.05 & 3.32 & 1.14 & 2.47 & 0.06 & 0.90 \\
\hline Mentzelia albicaulis leaves & & 0.13 & 0.27 & 0.09 & 0.05 & 0.04 & 0.19 & 0.17 \\
\hline Monardella exilis leaves & & 0.05 & 0.03 & & 2.93 & & & \\
\hline Moss & & 0.38 & & 0.03 & & 0.06 & 0.37 & \\
\hline Opuntia basilaris seed & & 3.13 & & 6.83 & & 1.86 & & 6.40 \\
\hline Opuntia basilaris stem & & 0.34 & 0.03 & 0.07 & 0.06 & 0.99 & 0.17 & 3.31 \\
\hline Pectocarya leaves & 0.61 & & 0.84 & 0.13 & & & 0.00 & 0.03 \\
\hline Phacelia/Nama leaves & 0.11 & & 0.18 & & 0.64 & & 0.11 & \\
\hline Poa secunda leaves & & 0.08 & & 0.15 & 0.02 & & & \\
\hline
\end{tabular}


APPENDIX 1. Continued.

\begin{tabular}{|c|c|c|c|c|c|c|c|c|}
\hline \multirow[b]{2}{*}{ Food item } & \multicolumn{2}{|c|}{ Site 1} & \multicolumn{2}{|c|}{ Site 2} & \multicolumn{2}{|c|}{ Site 3} & \multicolumn{2}{|c|}{ Site 4} \\
\hline & $\begin{array}{l}\text { Spring } \\
n=23\end{array}$ & $\begin{array}{c}\text { Summer } \\
n=55\end{array}$ & $\begin{array}{c}\text { Spring } \\
n=107\end{array}$ & $\begin{array}{c}\text { Summer } \\
n=115\end{array}$ & $\begin{array}{c}\text { Spring } \\
n=132\end{array}$ & $\begin{array}{c}\text { Summer } \\
n=133\end{array}$ & $\begin{array}{l}\text { Spring } \\
n=76\end{array}$ & $\begin{array}{c}\text { Summer } \\
n=113\end{array}$ \\
\hline \multicolumn{9}{|l|}{ Plant material } \\
\hline Pollen & & & 7.49 & & 0.13 & 2.15 & & 2.34 \\
\hline Root & & & & & 0.98 & & & 0.02 \\
\hline Salvia leaves & & & 2.96 & 0.14 & & & 0.18 & 0.03 \\
\hline Schismus leaves & 0.32 & 0.93 & 0.07 & 2.76 & 0.04 & & 0.17 & 0.01 \\
\hline Sphaeralcea ambigua leaves & 1.80 & 0.66 & & 0.02 & & 0.95 & 0.04 & 0.09 \\
\hline Stipa leaves & 0.14 & 0.05 & 0.24 & 0.87 & 0.10 & 0.10 & 0.28 & 0.11 \\
\hline Tetradymia leaves & 0.28 & & 0.07 & & 0.05 & & 0.04 & \\
\hline Unknown dicot leaves & 0.00 & 0.11 & 0.13 & 0.05 & & & 0.06 & 0.72 \\
\hline Unknown seed & & 3.50 & 0.05 & 0.17 & 0.04 & 1.05 & 0.11 & 0.80 \\
\hline Yucca brevifolia seed & & & 0.28 & & 0.07 & 0.11 & & 0.53 \\
\hline Other plant material ${ }^{\mathrm{a}}$ & & 0.05 & 0.17 & 0.12 & 0.07 & 0.15 & 0.06 & 0.12 \\
\hline \multicolumn{9}{|l|}{ Animal material } \\
\hline Arthropod parts & 1.23 & 4.72 & 1.74 & 4.57 & 1.89 & 2.59 & 1.44 & 1.94 \\
\hline Bone & & 0.34 & & & & & & \\
\hline TOTAL & 100.0 & 100.0 & 100.1 & 100.0 & 100.0 & 100.0 & 100.0 & 100.0 \\
\hline
\end{tabular}

aOther plant material contributions were very small $(<0.1$ percent mean relative density) in all sites and sampling periods. They include the following: bark, Boraginaceae seed, composite leaves, Delphinium parishii leaves, fern, Leptosyne (= Coreopsis) bigelovii leaves, lily leaves, Monardella exilis seed, Oenothera primiveris leaves, Plantago purshii leaves, Salsola tragus leaves, Stephanomeria leaves, Unknown grass leaves, and Yucca brevifolia leaves. 